\title{
Pre-sternal thyroid swellings: a case of rare aberrant site recurrence and review of literature
}

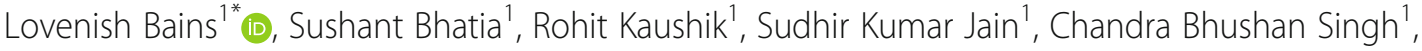
Shramana Mandal ${ }^{2}$ and Daljit Kaur ${ }^{3}$

\begin{abstract}
Background: Thyroid swellings enlarge caudally into the mediastinum behind the sternum. Pre-sternal swelling of thyroid origin is very rare. We present our case of pre-sternal thyroid swelling which was albeit a surprisingly rare site of papillary thyroid carcinoma recurrence and review of pre-sternal thyroid swellings reported till date.

Case summary: A 60 year old female presented with a painless, progressive swelling on the anterior part of the chest for the past 2 years. A $15 \mathrm{~cm} \times 8 \mathrm{~cm}$ vertically aligned, non tender, well defined swelling was present on the pre-sternal region, with consistency ranging from soft to firm. The swelling was fixed to the underlying tissues and a fixed level IV lymph node was palpable on the right side. Ultrasonography revealed a large mass of $15 \times 7 \mathrm{~cm}$ with multiple cystic areas. Fine needle aspiration cytology was inconclusive twice. Patient had undergone a total thyroidectomy for papillary carcinoma 10 years back. Computed tomography findings revealed a large $15 \times 6.6 \times 7 \mathrm{~cm}$ lobulated, presternal, soft tissue lesion with solid \& cystic components. The mass was infiltrating the right sided strap muscles and sternocleidomastoid. FNAC was inconclusive and thyroid scan could not pick up any activity in the mass. Henceforth a PET scan was done that showed increased FDG uptake by the lesion and the level IV lymph node. The patient underwent wide excision of the mass with right functional neck dissection, along with removal with both sternal head of sternocleido-mastoid, the strap muscles and the surrounding fascia. Histopathology confirmed papillary thyroid carcinoma. Patient received post-operative radioactive iodine ablation and is healthy with no recurrence up to 30 months of follow up.
\end{abstract}

Discussion: The mechanisms for pre-sternal thyroid swelling are not understood due to paucity of cases. The mechanisms proposed are invasion of strap muscles and cervical linea alba and tumor cells spread anterior to sternum, truly ectopic thyroid tissue, de novo carcinogenesis in the embryonal remnants like the thyro-thymic residues, sequestered thyroid tissue which grows later or migration of thyroid cells, incomplete clearance at the time of primary surgery or intraoperative seeding.

Conclusion: Pre-sternal region masses of thyroid origin are very rare. A proper work up, suspicion for thyroid mass and array of tests will be required to come to a provisional diagnosis. Since the masses reported in literature were primarily malignant, any such mass may be treated on lines of malignancy with radical surgery.

Keywords: Pre-sternal, Metastasis, Recurrence, Papillary thyroid carcinoma (PTC), Retrosternal, Substernal

\footnotetext{
* Correspondence: lovenishbains@gmail.com

'Department of Surgery, Maulana Azad Medical College, New Delhi, India

Full list of author information is available at the end of the article
}

(c) The Author(s). 2019 Open Access This article is distributed under the terms of the Creative Commons Attribution 4.0 International License (http://creativecommons.org/licenses/by/4.0/), which permits unrestricted use, distribution, and reproduction in any medium, provided you give appropriate credit to the original author(s) and the source, provide a link to the Creative Commons license, and indicate if changes were made. The Creative Commons Public Domain Dedication waiver (http://creativecommons.org/publicdomain/zero/1.0/) applies to the data made available in this article, unless otherwise stated. 


\section{Introduction}

Almost all the goiters that enlarge inferiorly go into anterior-superior mediastinum due to the attachment of pretracheal fascia to the superior aspect of the sternum. Due to variation in the definition of substernal goiter, the incidence has wide range from $2.6-21 \%$ of patients undergoing thyroidectomy $[1,2]$. The most commonly used definition states substernal goitre as a thyroid mass that has $50 \%$ or more of its volume located below the thoracic inlet. Substernal goiters represent up to $7 \%$ of mediastinal tumors [3]. Substernal goiter are always behind the sternum, extension in front of the sternum is very rare with limited 8 cases reported in indexed literature till date. Papillary thyroid carcinoma (PTC) is the most common form of well-differentiated thyroid cancer with a favorable prognosis. Recurrence rates of papillary thyroid carcinoma are in the range of $14-30 \%$, predominantly in the cervical region and distant metastasis is known mainly to lungs and bones [4]. No case of presternal recurrence of papillary thyroid carcinoma has ever been reported to the best of our knowledge in indexed literature. We present our unique case of 60 year old female with pre-sternal recurrence ten years after thyroidectomy.

\section{Case report}

A 60 year old female presented to our outpatient department with a painless, progressive swelling on the anterior part of the chest for the past 2 years. On examination, pulse rate was $78 / \mathrm{min}$, blood pressure $130 / 80 \mathrm{mmHg}$ and respiratory rate was $14 / \mathrm{min}$. A $15 \mathrm{~cm} \times 8 \mathrm{~cm}$ vertically aligned, non-tender, well defined swelling was present on the pre-sternal region, with consistency ranging from soft to firm (Fig. 1). The swelling was fixed to the underlying tissues. There was no visible neck swelling and retrosternal extension of this swelling was not appreciated. A 3 $\mathrm{cm} \times 2 \mathrm{~cm}$, hard, fixed level IV lymph node was palpable on the right side. Ultrasonography (USG) revealed a large mass of $15 \times 7 \mathrm{~cm}$ with multiple cystic areas. Fine needle aspiration cytology was inconclusive twice. Patient had undergone a total thyroidectomy for papillary carcinoma 10 years back. No records were available and there was no history of radio iodine ablation therapy. Patient was taking 100 micrograms thyroxine daily. Her thyroid function tests were normal (TSH $3.1 \mathrm{uIU} / \mathrm{ml}$; refence range 0.35 5.50). Her hemoglobin was $11 \mathrm{~g} \%$ and laboratory parameters including kidney function tests within normal range. Computed tomography findings revealed a large $15 \times$ $6.6 \times 7 \mathrm{~cm}$ lobulated, pre-sternal, soft tissue lesion with solid \& cystic components (Fig. 2). No underlying bony destruction or retro sternal extension was seen. No cervical lymphadenopathy was seen besides a $3 \times 2 \mathrm{~cm}$ level IV node. The mass was infiltrating the right sided strap muscles and sternocleidomastoid. In view of invasion, Magnetic resonance imaging was also done, which revealed a large $14 \times 6.5 \times 7 \mathrm{~cm}$ well defined, multicystic lesion with solid components in the anterior aspect of lower neck extending inferiorly in the pre-sternal region (Figs. 3 and 4). The lesion shows ill-defined planes with bilateral sternocleido-mastoid muscles and the strap muscles.

A suspicion of recurrence of papillary thyroid cancer was thought in this rare location. Thyroid scan could not pick up any activity in the mass. Henceforth a PET scan was done that showed increased FDG uptake by the lesion and the level IV lymph node (Fig. 5). USG guided fine needle aspiration cytology was done again and showed Bethesda IV category. The patient underwent wide excision of the mass with right functional neck dissection. The mass was attached to the sternal head of the right sternocleido-mastoid and other strap muscles. The mass was removed with both sternal head of sternocleido-mastoid, the strap muscles and the surrounding fascia (Figs. 6 and 7).

The gross specimen revealed solid components with multiple cystic areas (Fig. 8). Histopathology confirmed well differentiated papillary thyroid carcinoma with presence of typical cells, nuclear groves, inclusions and clustering. Focal area of necrosis and hemosiderin laden macrophages were also present (Fig. 9). Resected margins were clear. Labelled lymph node showed deposits of papillary carcinoma thyroid; included fibro collagenous tissue also showed deposits of papillary carcinoma thyroid. Post-operative radioactive iodine ablation $70 \mathrm{mCi}$ was given approximately 8 weeks after the surgery. The
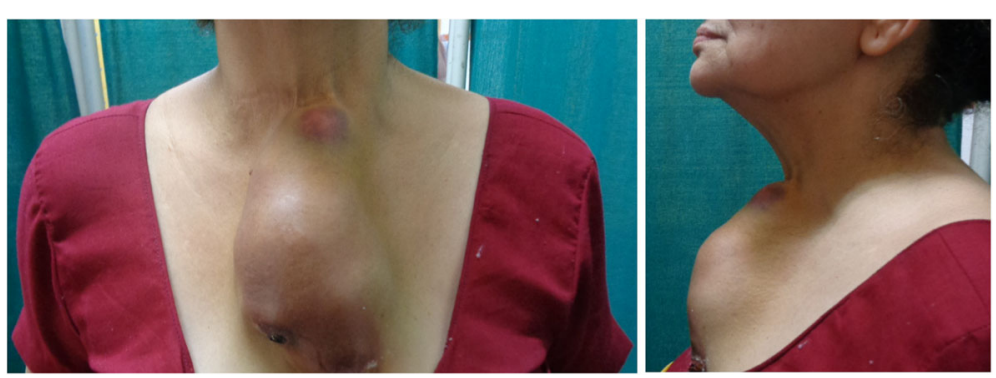

Fig. 1 Pre-sternal swelling of $15 \mathrm{~cm} \times 8 \mathrm{~cm}$ - anterior view \& lateral view 


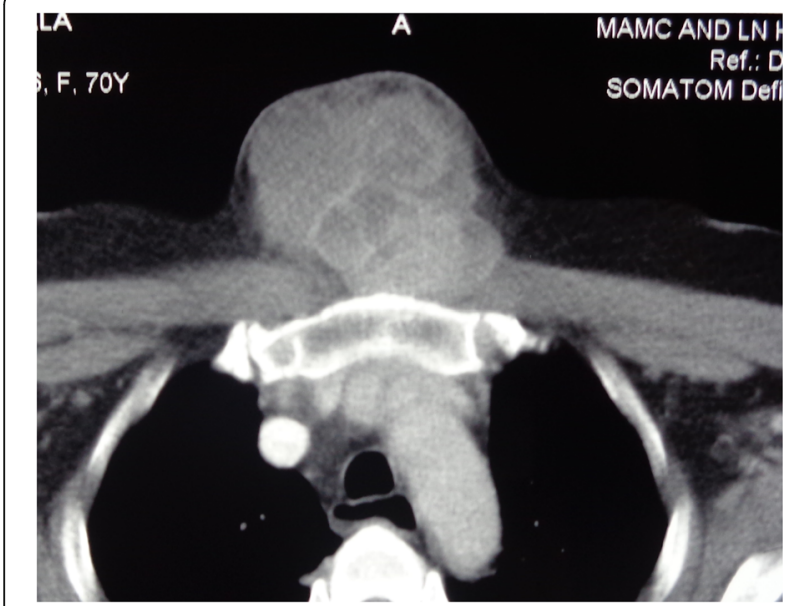

Fig. 2 CT scan showing soft tissue mass anterior to sternum

thyroglobulin levels have been less than 1 microgram/L. The patient has been following regularly and is healthy with no recurrence up to 30 months of follow up.

\section{Discussion}

Papillary thyroid carcinoma is the most common endocrine and thyroid cancer which accounts for $85 \%$ of all thyroid malignancies. Its incidence has been increasing worldwide as indicated by Surveillance, Epidemiology, and End Results (SEER) database from 1975 to 1992 when it increased from 4.8 to 5.8 per 100,000; however from 1992 to 2016, the incidence of papillary cancer has increased significantly from 5.8 to 14.1 per 100,000 [5].

Despite its well-differentiated characteristics, papillary carcinoma may be overtly or minimally invasive. In fact, these tumors may spread easily to other organs. Papillary carcinoma appears as an irregular solid or cystic mass or nodule in a normal thyroid parenchyma. Papillary

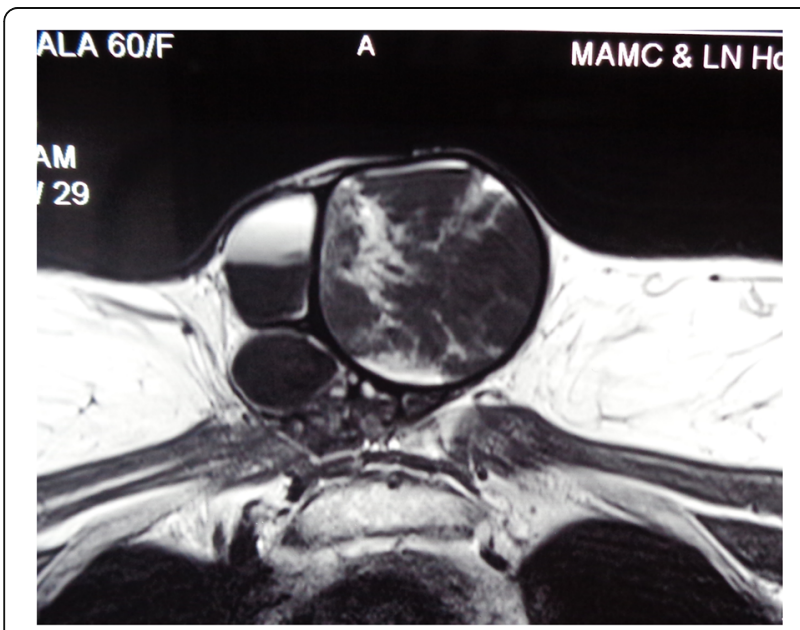

Fig. $3 \mathrm{MRI}$ coronal view showing large pre-sternal mass



Fig. $4 \mathrm{MRI}$ sagittal view- multicystic lesion

tumors have a propensity to invade lymphatics but are less likely to invade blood vessels. These tumors are indolent and have a good prognosis, but frequently metastasize to regional lymph nodes in 5.4 to $13 \%$ of patients after initial surgery [6]. Recurrence rate after primary treatment is $1.8 \%$ annually for the first 10 years.

The 10-year, 20-year and 30-year recurrence rates were $11.3,21.8$ and $29.4 \%$, respectively. The risk of recurrence of the disease is the greatest in the first 5 years (36.9\%) after the initial treatment whereas $54.8 \%$ happened within the first 10 years [7]. Though the recurrence can occur any time, but maximum reported time was 43 years following total thyroidectomy and radioactive iodine ablation [8].

Local sites of recurrence include the cervical lymph nodes and the remaining thyroid tissue. Distant metastasis usually happens to bones and lungs, but less common sites include brain, adrenal, skeletal muscle [9]. Other rare sites have been liver, skin, parapharyngeal space and right atrium [10]. Risk factors implicated for loco regional recurrence are age, histological grade, distant metastases, extracapsular tumor extension, tumor size, and stage of disease [11].

Lymph node metastases are a debatable prognostic factor, having relevance in recurrence of disease, but have no relevance in survival rate of patients [12]. Recurrence increases with the number of metastatic nodes and the degree of metastasis, as well as with extracapsular infiltration and age [13]. This study also demonstrates that the presence of lymphatic permeation in the primary tumor correlates to an $84.4 \%$ probability of 
Table 1 Details of pre-sternal thyroid swellings reported till date

\begin{tabular}{|c|c|c|c|c|c|c|}
\hline $\mathrm{Sno}$ & Author & Year & Age & Sex & Findings & Nature of mass \\
\hline 1 & Belger S [23]. & 1952 & & & Details not available & \\
\hline 2 & Raman A et al. [21] & 1999 & 39 & $\mathrm{~F}$ & $\begin{array}{l}15 \times 30 \mathrm{~cm} \\
\text { Lobular cystic swelling on the anterior aspect of the } \\
\text { neck from submental region to the xiphisternum in } \\
\text { the pre-sternal plane }\end{array}$ & $\begin{array}{l}\text { Papillary carcinoma thyroid with } \\
\text { metastasis in regional lymph nodes }\end{array}$ \\
\hline 3 & Brilli L et al. [24] & 2007 & 50 & M & $\begin{array}{l}10 \mathrm{~cm} \text { in length } \\
\text { Elongated neck mass, descending subcutaneously up } \\
\text { to the mid region of the sternum. }\end{array}$ & Multinodular goiter \\
\hline 4 & Chow TL et al. [19] & 2014 & 50 & M & $\begin{array}{l}3.5 \times 3 \mathrm{~cm} \\
\text { dumb-bell-shaped mass, lower part in pre-sternal plane }\end{array}$ & Papillary carcinoma thyroid \\
\hline 5 & Fanantenana HN et al. [20] & 2015 & 60 & M & $\begin{array}{l}18 \times 14 \mathrm{~cm} \\
\text { Firm, smooth surface mass } \\
{ }^{*} \mathrm{H} / \mathrm{o} \text { excision } 7 \text { years ago. }\end{array}$ & $\begin{array}{l}\text { Heterotopic thyroid goitre with } \\
\text { no evidence of malignancy. }\end{array}$ \\
\hline 6 & Patil et al. [25] & 2012 & 60 & $\mathrm{~F}$ & $\begin{array}{l}25 \times 15 \mathrm{~cm} \\
\text { Mass arising from neck with multiple cysts in front } \\
\text { of sternum }\end{array}$ & Papillary carcinoma thyroid \\
\hline 7 & Tang et al. [26] & 2015 & 42 & M & $\begin{array}{l}17 \times 13 \mathrm{~cm} \\
\text { Multiple cystic lesions in the chest beneath skin } \\
\text { interlinked with the right thyroid lobe }\end{array}$ & Papillary thyroid microcarcinoma \\
\hline 8 & Stumpf et al. [22] & 2017 & 54 & $\mathrm{~F}$ & $\begin{array}{l}20 \times 9 \mathrm{~cm} \\
\text { Large, firm, regular mass in pre-sternal region } \\
{ }^{*} \mathrm{H} / \mathrm{O} \text { partial thyroidectomy } 13 \text { years ago. }\end{array}$ & Colloid goiter \\
\hline 9 & Bains $L$ et al & 2019 & 60 & $\mathrm{~F}$ & $15 \times 8 \mathrm{~cm}$ & Papillary carcinoma thyroid recurren \\
\hline
\end{tabular}



Fig. 5 PET CT showing FDG uptake in the mass and neck node lymphatic metastasis. As with primary tumor size was of $3.8 \mathrm{~cm}$ versus $1.98 \mathrm{~cm}$, only lymphatic permeation was correlated to an increase in metastasis in lymph nodes $65.4 \%$ versus $25 \%(p<0.001)$. The metastatic frequency for cervical lymph node regions was IIa $18.5 \%$ versus $1.5 \%$, III $24.3 \%$ versus $9.9 \%$, IV $17.4 \%$ versus $18.1 \%$, and VI $25.9 \%$ versus $71,2 \%$ [14].

The prognosis for PTC is better than for other types of thyroid cancer; however, the involvement of lymph nodes (LNs) is up to $15-30 \%$ at diagnosis [15]. The 5



Fig. 6 Pre-operative and intra-operative picture of the mass 




Fig. 7 Resected specimen

year survival rate for local disease is near $100 \%$, regional disease is near $100 \%$ and distant disease is $78 \%$ [16]. It is generally accepted that the spread pattern of LN in PTC is central compartment, ipsilateral compartment, and contralateral compartment sequentially. The factors that associated with contralateral LN metastasis were male gender, more than $2 \mathrm{~cm}$ size of main tumor, multifocality, bilaterality, and extra thyroidal extension.

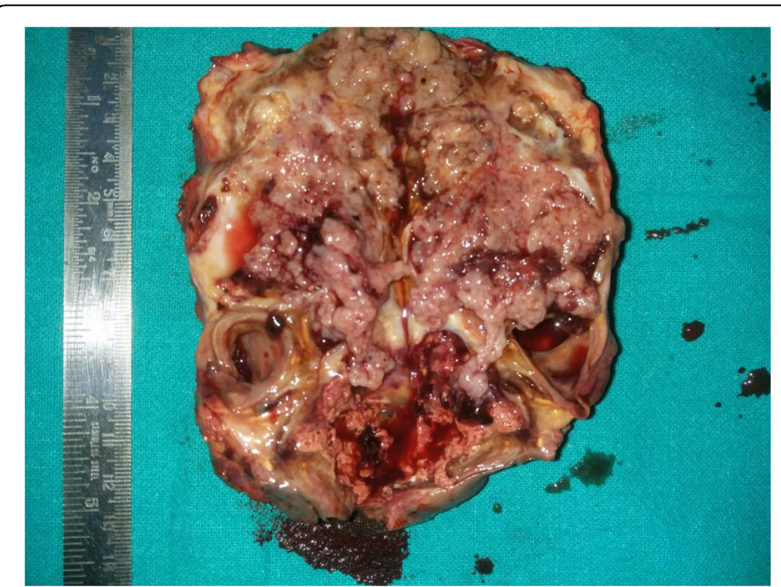

Fig. 8 Specimen showing multiple cystic and solid areas

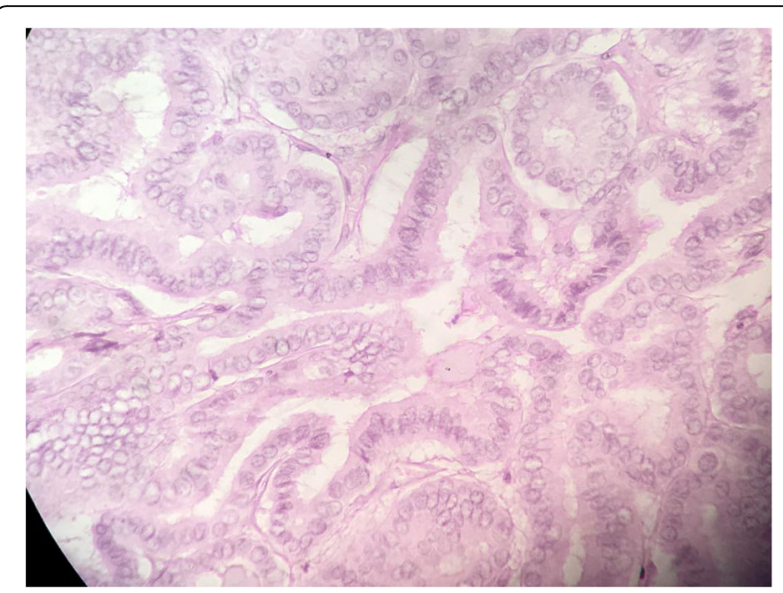

Fig. 9 HPE consistent with papillary thyroid carcinoma. H \& E stain

Retrosternal goiter was first described by Haller in 1749 [17]. Substernal goiters are largely considered to result from the descent of a cervical goiter with the primary blood supply remaining in the neck, primarily from the inferior thyroid artery. Thereafter. thyroid gland enlarges into the retrosternal area owing its position beneath the pre-tracheal fascia and the strap muscles, all of which are attached to the top of manubrium.

Several factors favor the passage of the goiter into the mediastinum: Downward traction caused by normal swallowing, respiration creating negative intrathoracic pressure, and the pull of gravity on the goiter [18]. Some theories postulate that small cervical thyroid nodules descend beneath the pre-tracheal fascia, possibly aided by the negative intrathoracic pressures that normally occur during respiration and swallowing. As the nodule gradually enlarges, it eventually becomes trapped below the thoracic inlet, where it continues to enlarge within the confines of the thoracic cavity, commonly hidden from view and causes compressive effects as it enlarges. Malignancy can occur in 5-26.9\% of substernal goiters [2].

By extensive search of literature we found only 8 reported cases (Table 1). These cases were essentially pre-sternal extension of the primary mass (multinodular goiter in one and papillary cancer in four) with heterotopic thyroid tissue in one and recurrence of colloid goiter in one. Details were not available for one case. Despite many cases of recurrence at unusual sites, no recurrence presenting as a pre-sternal mass has been reported. Pre-sternal thyroid swelling thus remains exceptionally rare presentation.

The mechanisms for pre-sternal presentation are not understood due to paucity of cases. The following mechanisms can be proposed. 
- invasion of strap muscles and cervical linea alba and tumor cells spread anterior to sternum [19]

- truly ectopic thyroid tissue [20]

- De novo carcinogenesis in the embryonal remnants like the thyro-thymic residues

- sequestered thyroid tissue which grows later or migration of thyroid cells [21]

- incomplete clearance at the time of primary surgery or intraoperative seeding [22]

\section{Conclusion}

Pre sternal region masses of thyroid origin are exceptionally rare. A proper work up, suspicion for thyroid mass and array of tests will be required to come to a provisional diagnosis. Since the masses reported in literature were primarily malignant, any such mass may be treated on lines of malignancy with radical surgery.

\section{Abbreviations}

$\mathrm{CT}$ : Computed tomography; FDG: Fluorodeoxyglucose; FNAC: Fine needle aspiration cytology; LN: Lymph node; MRI: Magnetic resonance imaging; PET: Positron emission tomography; PTC: Papillary thyroid carcinoma; USG: Ultrasonography

\section{Acknowledgements}

Nil

\section{Authors' contributions}

$L B, S B, R K$ conceptualized the manuscript, reviewed the literature, analyzed data, and made major contribution to the writing of the manuscript. LB, SB, RK, SKJ, CBS, performed the clinical examination, surgical treatment, and clinical follow-up. SM provided the histopathological diagnosis. LB, SB, RK, SKJ, CBS, DK performed final review and editing of the of the manuscript. All authors have read and approved the final version of the manuscript.

\section{Funding}

None.

\section{Availability of data and materials}

Not available.

\section{Ethics approval and consent to participate}

Written consent for the publication of this case report was obtained from the patient. Approval for case report by the institutional ethics committee is not required.

\section{Consent for publication}

Written informed consent for the publication of this case report and for the accompanying images was obtained from the patient. A copy of the written consent is available for review by the Editor-in-Chief of this journal.

\section{Competing interests}

The authors declare that they have no competing interests.

\section{Author details}

${ }^{1}$ Department of Surgery, Maulana Azad Medical College, New Delhi, India. 2Department of Pathology, Maulana Azad Medical College, New Delhi, India. ${ }^{3}$ Department of Transfusion Medicine, All India Institute of Medical Sciences, Rishikesh, India.

Received: 3 October 2019 Accepted: 13 November 2019 Published online: 21 November 2019

\section{References}

1. Moron JC, Singer JA, Sardi A. Retrosternal goiter: a six-year institutional review. Am Surg. 1998;64(9):889-93.
2. Khairy GA, Al-Saif AA, Alnassar SA, Hajjar WM. Surgical management of retrosternal goiter: local experience at a university hospital. Ann Thorac Med. 2012;7(2):57-60. https://doi.org/10.4103/1817-1737.94520.

3. Raffaelli M, De Crea C, Ronti S, Bellantone R, Lombardi CP. Substernal goiters: incidence, surgical approach, and complications in a tertiary care referral center. Head Neck. 2011;33(10):1420-5. https://doi.org/10.1002/hed. 21617 Epub 2010 Nov 10.

4. Dinneen SF, Valimaki MJ, Bergstralh EJ, Goellner JR, Gorman CA, Hay ID. Distant metastases in papillary thyroid carcinoma: 100 cases observed at one institution during 5 decades. J Clin Endocrinol Metab. 1995;80(7):2041-5.

5. https://seer.cancer.gov/statfacts/html/thyro.html Accessed on 18.04.2019.

6. Roh $J \mathrm{~L}$, Park JY, Rha KS, Park Cl. Is central neck dissection necessary for the treatment of lateral cervical nodal recurrence of papillary thyroid carcinoma? Head Neck. 2007;29(10):901-6.

7. Dong W, Horiuchi K, Tokumitsu H, Sakamoto A, Noguchi E, Ueda Y, Okamoto T. Time-varying pattern of mortality and recurrence from papillary thyroid Cancer: lessons from a long-term follow-up. Thyroid. 2019. https:// doi.org/10.1089/thy.2018.0128 [Epub ahead of print].

8. Amoako-Tuffour Y, Graham ME, Bullock M, Rigby MH, Trites J, Taylor SM, Hart RD. Papillary thyroid cancer recurrence 43 years following Total thyroidectomy and radioactive iodine ablation: a case report. Thyroid Res. 2017;10:8. https://doi.org/10.1186/s13044-017-0043-4 eCollection 2017.

9. Herbowski L. Skeletal muscle metastases from papillary and follicular thyroid carcinomas: an extensive review of the literature. Oncol Lett. 2018;15(5): 7083-9. https://doi.org/10.3892/ol.2018.8216.

10. Portela RA, Choby GW, Manni A, Campbell D, Crist H, Goldenberg D. Unusual sites of metastasis of papillary thyroid cancer: case series and review of the literature. Ear Nose Throat J. 2015;94(8):E43-7.

11. Maksimovic S, Jakovljevic B, Gojkovic Z. Lymph node metastases papillary thyroid carcinoma and their importance in recurrence of disease. Med Arch. 2018;72(2):108-11. https://doi.org/10.5455/medarh.2018.72.108-111.

12. Guo K, Wang Z. Risk factors influencing the recurrence of papillary thyroid carcinoma: a systematic review and meta-analysis. Int J Clin Exp Pathol. 2014;7(9):5393-403 eCollection 2014.

13. Randolph GW, Duh QY, Heller KS, LiVolsi VA, Mandel SJ, Steward DL, Tufano RP, Tuttle RM, American Thyroid Association Surgical Affairs Committee's Taskforce on Thyroid Cancer Nodal Surgery. The prognostic significance of nodal metastases from papillary thyroid carcinoma can be stratified based on the size and number of metastatic lymph nodes, as well as the presence of extranodal extension. Thyroid. 2012;22(11):1144-52. https://doi.org/10. 1089/thy.2012.0043 Epub 2012 Oct 19.

14. Hurtado-López LM, Ordoñez-Rueda A, Zaldivar-Ramírez FR, Basurto-Kuba E. Regional Node Distribution in Papillary Thyroid Cancer with Microscopic Metastasis. J Thyroid Res. 2018;2018:1718284. Published 2018 Nov 1. https:// doi.org/10.1155/2018/1718284

15. Shaha AR, Shah JP, Loree TR. Patterns of nodal and distant metastasis based on histologic varieties in differentiated carcinoma of the thyroid. Am J Surg. 1996;172(6):692-4

16. https://www.cancer.org/cancer/thyroid-cancer/detection-diagnosis-staging/ survival-rates.html Accessed on 18.04.2019.

17. Haller A. Disputationes Anatomicae Selectae, Gottingen. Holland: Vandenhoeck; 1749. p. 96.

18. Sianesi M, Del Rio P, Arcuri MF, Soliani P, Rusca M. Cervico-mediastinal goiter. Chir Ital. 2002;54(1):15-8.

19. Chow TL, Kwan WW, Hui JY. Malignant pre-sternal goitre. Hong Kong Med J. 2014;20(2):156-7. https://doi.org/10.12809/hkmj133946.

20. Fanantenana HN, Hasina RN, Hery R, Claude RA, Ahmad A. An observation of a goitre on pre-sternal thyroid dysgenesis [Goiter on pre-sternal thyroid dysgenesis]. Pan Afr Med J. 2015;21:117. Published 2015 Jun 12. https://doi. org/10.11604/pamj.2015.21.117.6919.

21. Raman A, Nair A. Pre-sternal extension of a malignant thyroid swelling. Aust N Z J Surg. 1999:69(3):241-2.

22. Stumpf MAM, Marques AS, Kluthcovsky ACGC, Belonci CGC. Pre-sternal Goiter. JCPSP. 2019:29(6):574-6.

23. Belger S. A case of sub-cutaneous pre-sternal cystic goiter. Minerva Chir. 1952;7(7):253-4

24. Brilli L, Guarino E, Ghezzi M, Carli AF, Occhini R, Pacini F. Multinodular goiter of unusual shape and location. Thyroid. 2007;17(7):693-4.

25. Patil VS, Vijayakumar A, Natikar N. Unusual presentation of cystic papillary thyroid carcinoma. Case Rep Endocrinol. 2012;2012:732715. https://doi.org/ $10.1155 / 2012 / 732715$. 
26. Tang ZN, Liu QL, Hu ZQ, Wu LG. A rare presentation of a large goiter with papillary thyroid microcarcinoma as a chest wall mass: a case report. Mol Clin Oncol. 2016;4(3):461-3. https://doi.org/10.3892/mco.2016.730.

\section{Publisher's Note}

Springer Nature remains neutral with regard to jurisdictional claims in published maps and institutional affiliations.

Ready to submit your research? Choose BMC and benefit from:

- fast, convenient online submission

- thorough peer review by experienced researchers in your field

- rapid publication on acceptance

- support for research data, including large and complex data types

- gold Open Access which fosters wider collaboration and increased citations

- maximum visibility for your research: over $100 \mathrm{M}$ website views per year

At BMC, research is always in progress.

Learn more biomedcentral.com/submissions 